\title{
Esprit cartésien? Issues concerning the influence of Descartes on the works of Nicolas Poussin
}

\author{
HENRY KEAZOR
}

The introduction to a recent French monograph on Descartes and his philosophy featured the following statement:

L'esprit cartésien n'a pas très bonne image aujourd'hui. Il est souvent synonyme d'un rationalisme autoritaire et réducteur. ${ }^{\mathrm{I}}$

This quite negative appraisal is contradicted elsewhere in which it is postulated that Cartesian philosophy was and remains fundamental to our way of perceiving and conceiving our own reality:

... nicht wenige unserer Ansichten über Seele und Körper, Subjekt und Objekt, die wir für selbstverständlich halten, weil wir über sie nicht nachzudenken pflegen, sind in Wirklichkeit nicht selbstverständlich, sondern cartesianisch. ${ }^{2}$

When comparing these two quotations taken from two different monographs on the philosopher it appears that our attitude to Cartesian philosophy is schizophrenic: for whilst many of our ideas and concepts, which we take for granted, are Cartesian in origin we reject this 'Cartesian mentality' when the notion of it becomes explicit.

It is already a difficult task to agree univocally on the extent to which in this day and age we are moulded by the Cartesian imprint and yet more difficult to define the impact Descartes had on his contemporaries. But such definition is all the more important in view of the fact that it has become obligatory to evaluate the significance and role of philosophical concepts through their repercussions, the way in which they were received by their contemporaries and succeeding generations. The case for presentation and analysis in this paper is even more significant for it deals not simply with how a contemporary philosopher of Descartes may have become acquainted with his ideas, but whether in transgressing the boundaries of scientific disciplines, an artist (and here it must be emphasized, one of the most intellectual artists of his time) had registered such response to the philosophy in his work. A fact, if established, which would make the influence of the philosopher even more remarkable.

Thus the question posed is whether Nicolas Poussin (figure $\mathrm{I}),{ }^{3}$ frequently dubbed a 'peintre philosophe', ${ }^{4}$ assimilated the ideas of René Descartes, as has been often and quite diversely maintained (figure 2 ) ${ }^{5}$ For his part the philosopher not only treated matters of extreme interest to painters such as optics but also occasionally resorted to art

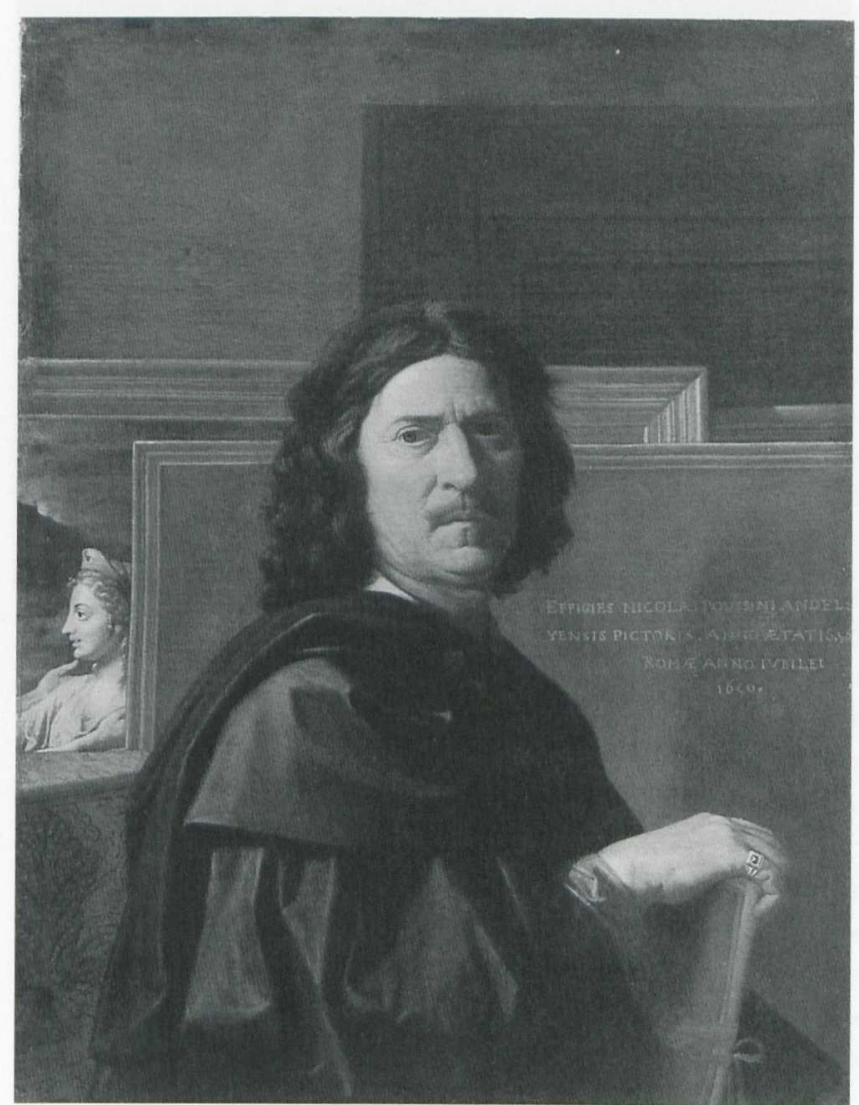

Figure 1. Nicolas Poussin, Self-Portrait. Paris, Louvre, I650.

metaphors in his writings. ${ }^{6}$ In Discourse de la méthode (1637) he asserted that his desire was to represent his life 'comme en un tableau'. ${ }^{7}$ Moreover, he explained his intention of presenting only a few examples of his new method pars pro toto by demonstrating only results from his work in optics, as bearing comparison with painters who are compelled to choose the main side of a three-dimensional body in order to paint it on canvas; ${ }^{8}$ similarly he has chosen to select the results obtained from his work in optics to indicate the range of his new method. In Dioptrique he mentioned the experience gained by the so-called 'taille-douces' (engravings) to affirm the difference between visible things and their images, which, however, must resemble them up to a certain 


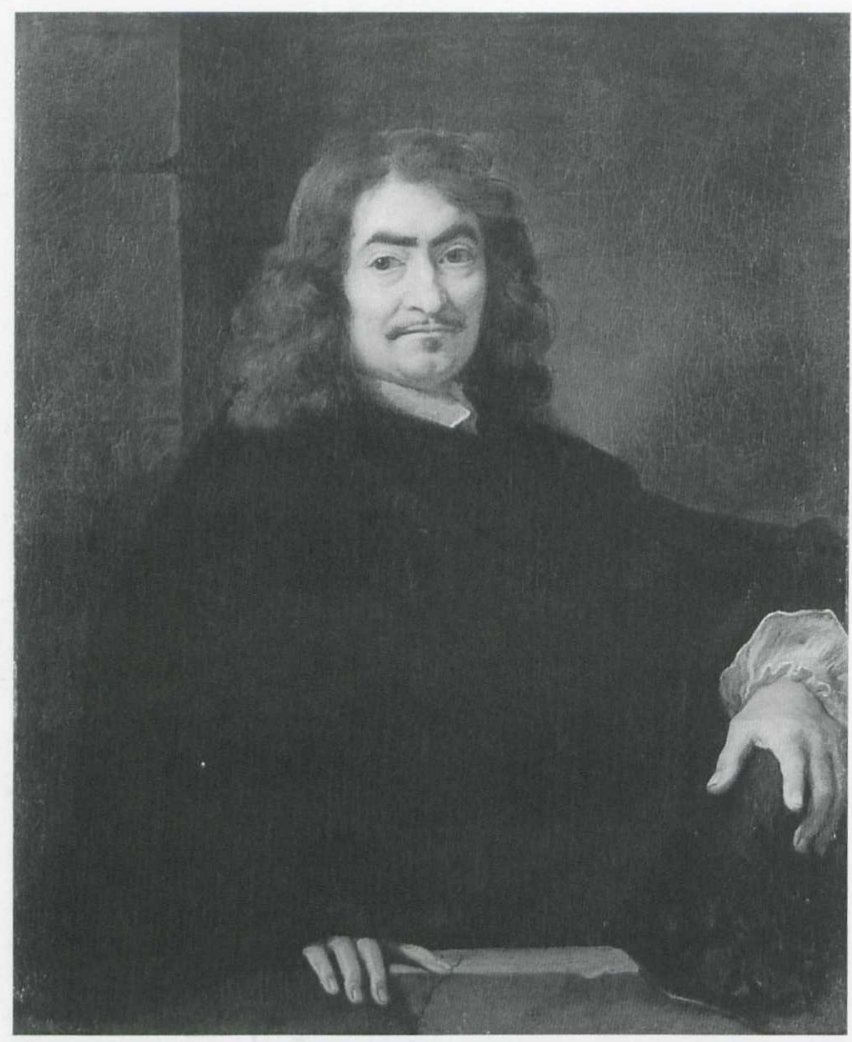

Figure 2. Sébastien Bourdon, Portrait of René Descartes. Paris, Louvre, I649 (Inv. No. 2812).

point. ${ }^{9} \mathrm{He}$ emphasizes here that one is able to interpret the simple ink lines on paper of an engraving as things depicted and although the objects represented in this way do not bear a one hundred percent resemblance to the original, we can indeed recognize them. Hence we recognize an object as round or square even if perspectival distortions turn it into an oval or rhomboid (figure 3 ). ${ }^{10}$ It seems pointless to once more call attention to the repetitive use of the term 'peinture' utilized in the Dioptrique to signify the image projected on the retina.$^{I 1}$ Finally, in the Meditationes de prima philosophia (I64I) he asserted that even though the things created by painters are merely imaginary, at least the colours with which these fantasies were painted do indeed physically exist. ${ }^{12}$

A clarification of what up to now is only a presumed relationship between the 'peintre philosophe' Poussin and the philosopher Descartes, who used artistic metaphors poignantly, could yield some useful results:

I. It could serve as a 'touchstone' to verify the validity of arguments used to ground the hypotheses linking other artists to Descartes.

2. If successful in the first point another example could be added concerning the assimilation of Cartesian ideas, the analysis of which would assist in comprehending which ideas had such repercussions and why.

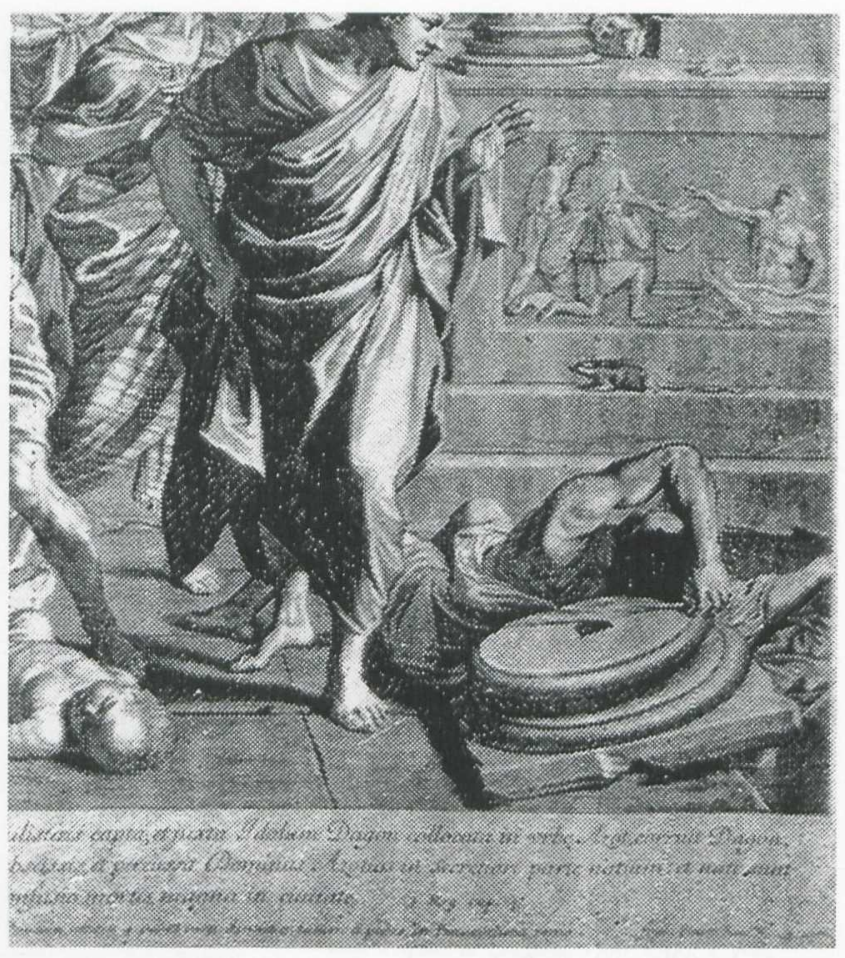

Figure 3. Details from an engraving by Etienne Picart after Poussin's 'The Plague at Ashdod', i677.

3. Should the first point fail, however, it would make us more cautious in the future when tempted to attribute certain modes of thinking to Descartes only because they resemble Cartesian ideas. Furthermore, such a negative result would help us better understand the indisputable impact of Descartes. The fact that his contemporaries nurtured ideas similar to his - which at first glance appear to tell of his influence - perhaps indicates that others had already ploughed the ground for such thoughts and that Descartes himself had grasped, absorbed and summarized the intellectual currents of his era.

If we now turn to the matter of Descartes's influence on Nicolas Poussin's painting we are compelled to deal with the great paradox that Descartes's fundamental method of systematic doubt ('De omnibus dubitandum') has never been applied to this issue. Indeed, rather than paying heed to the first rule of the Discours de la méthode - 'never to accept anything as true which I do not clearly and distinctly see to be so, ${ }^{13}$ we discover simple undemonstrated affirmations of his influence repeated with varying degrees of intensity. These range from a stating of the fact of their mere contemporaneity to blank assertions of a presumed influence of Descartes on Poussin. Observing the second and third Cartesian rules to 'divide each of the difficulties under examination into as many parts as possible' and 'to conduct my thoughts in order, beginning with the objects that are the 
simplest and easiest to know and so proceed, gradually, to knowledge of the more complex', ${ }^{14}$ the following panorama reveals itself.

Anthony Blunt, for instance, confined himself to mentioning that Descartes and Poussin were contemporaries; ${ }^{15}$ yet documents indicate that they never actually met, unlike the painters Frans Hals or Sébastien Bourdon, ${ }^{16}$ who both painted portraits of the philosopher (see figure 2). When in ${ }_{1} 624$ Descartes arrived in Venice, ${ }^{17}$ Poussin had already left for Rome. Though they were both to spend the autumn and winter of that Holy Year in the ancient capital no meeting or even acknowledgment of each other has been recorded - both of them were quite unknown at the time. When famous and living abroad, ${ }^{18}$ Descartes in The Netherlands and Poussin in Rome, they missed each other when they chose to return to France. Poussin was there between I640 and I64I, whereas the philosopher visited Paris three years afterwards with the artist settled again in Rome. ${ }^{19}$ The possibility of Poussin being in Paris and in the absence of Descartes still coming into contact with members of his intellectual circle appears to be denied by what sources tell us. A letter from Bourdelot, dated I May i642, features the guest list of a Paris dinner party where Poussin is listed clearly as sitting next to none other than Pierre GassendiDescartes's great and impetuous adversary. ${ }^{20}$

In view of this apparent total lack of any direct, personal contact between the painter and philosopher, we can proceed to the next level of our considerations: examining the possibility of an intellectual affinity between the two extending beyond pure and simple contemporaneity or a personal meeting.

As early as I9o4 Paul Desjardins's book (the title being demonstrably Cartesian sounding in itself) La Méthode (note the capital 'M'!) des classiques français, offered a view of Poussin, which, according to Marc Fumaroli's interpretation, presents the painter alongside Descartes, Corneille and Pascal as the antidote for the romanticism of the 'great vagueness' $^{21}$ and troubles of the early twentieth century. What appears to link the painter and philosopher are not only the key word 'method', but also the 'scientific discipline' that distinguishes them both. In the case of Poussin, Fumaroli states that the discipline assures that 'the truth blossoms throughout with its secret and definite laws'. ${ }^{22}$ It is precisely because of this apparent bond between 'scientific discipline' and the 'secret and definite laws' that such duality is more and more frequently repeated in the subsequent literature on Descartes and Poussin, and thus became cemented, but only slightly developed, explained or demonstrated.

The first attempt at explaining the trio of Descartes, Corneille and Poussin ${ }^{23}$ evoked by Desjardins involves mainly the philosophic concept that would unite the three personalities and would then, in a second instance, function as the background for the method all three applied.
However, before examining this method more closely we should first analyse the philosophical concept presumed to be common to Descartes and Poussin.

Erwin Panofsky in 1939 drew a parallel between the painter and philosopher in this manner:

... in the visual arts a calmer, nearly Cartesian mind [exactly our 'esprit cartésien'] was to create the unsurpassable images of Time as a cosmic power: Nicolas Poussin. ${ }^{24}$

Taking Poussin's famous self-portrait in the Louvre (see figure I) as his starting point, in I966, Walter Friedländer wrote:

He showed himself, as he wanted to be seen and understood for all time: as the peintre-philosophe, the creative and meditative architect of spatial and human relationships - as the spiritual equal of Corneille and Descartes. ${ }^{25}$

Words such as 'calmer mind' and 'meditative architect' indicate the course taken by the studies on the common concepts of Corneille, Descartes and Poussin. Friedländer summarizes the results with the following:

The general affinity which has often been observed between Nicolas Poussin and two of his French contemporaries, is based partly upon the Stoic conceptions underlying the work of all three. ${ }^{26}$

At first glance there appear to be clear hints in the writings of both Poussin and Descartes, which could sustain such a hypothesis. They both use the metaphor of the 'great book of the world', ${ }^{27}$ always called upon to contrast with the merely theoretical, that which is only read and is thus secondhand knowledge. ${ }^{28}$ This image was present in late Roman literature, in particular the work of St Augustine, but here it is taken from Montaigne, ${ }^{29}$ a model of Stoicism actually lived by the philosopher. The metaphor of the world as a theatre also surfaces and can be traced to the 'Enchiridion' by the stoic philosopher Epictetus; ${ }^{30}$ the notion here is that the world must only be viewed from a distance, ${ }^{31}$ as Poussin wrote in a letter to Paul Fréart de Chantalou in I643, 'to enjoy the gestures of the actors'. ${ }^{2}$ Similar words can be detected in Descartes's Discours, and may be reflected in Jan Baptist Weenix's portrait (figure 4), which features the philosopher holding an open book displaying the inscription 'Mundus est fabula'. ${ }^{33}$ And when reading a sentence such as:

... toutes vos actions estant conduittes par le moyen de la raison vous ne pouués rien faire qui n'aye une fin vrayement vertueuse $^{34}$

and comparing it with this statement:

... il suffit de bien juger, pour bien faire, \& de juger le mieux qu'on puisse, pour faire aussy tout son mieux, c'est à dire pour acquerir toutest les vertus ... ${ }^{35}$

it is difficult to attribute either of these quotations to Poussin or Descartes with any certainty. At any rate, as has been 


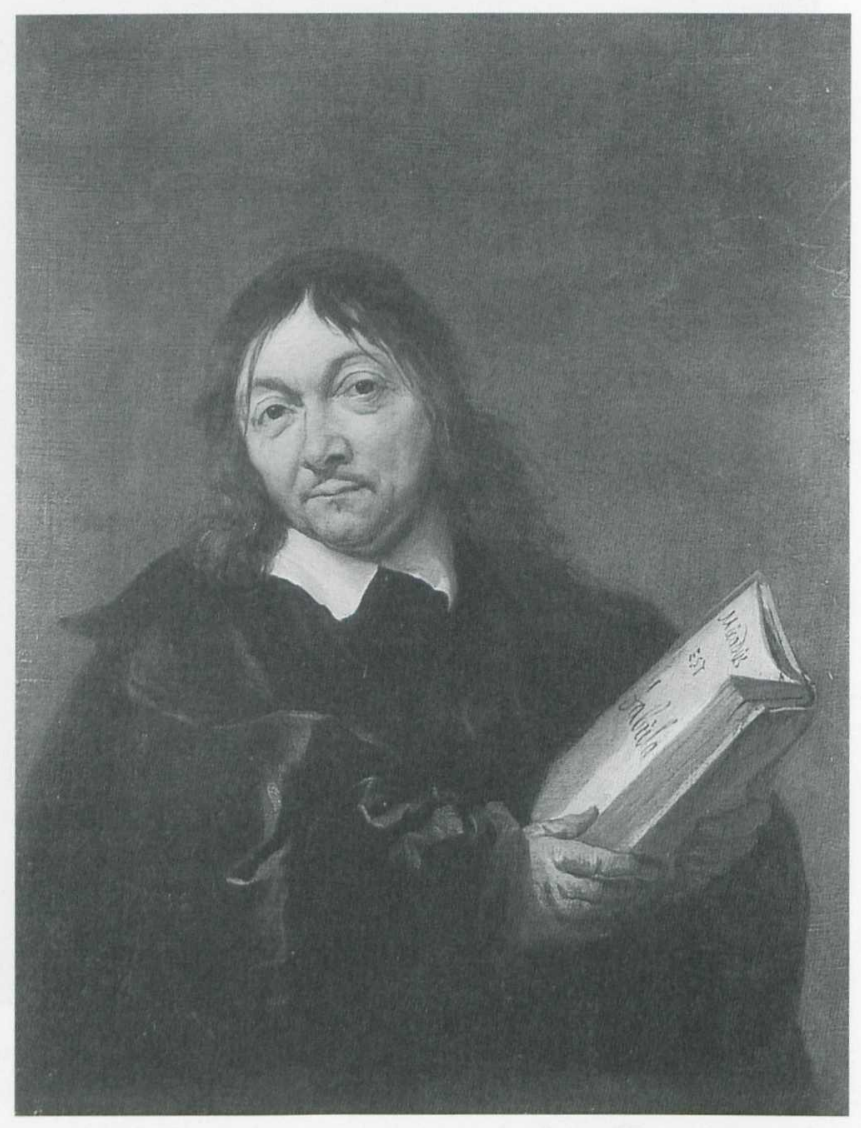

Figure 4. Jan Baptist Weenix, Portrait of René Descartes. Utrecht, Centraal Museum; $c$. I647.

emphasized elsewhere ${ }^{36}$ both writers invite their audiences to act patiently and discerningly, criticizing,

... ceux qui ... ne se peuuent empescher de precipter leurs jugements, ny auoir assez de patience pour conduire par ordre toutes leurs pensées ${ }^{37}$

rather than looking at things with 'temp jugement et intelligense.' ${ }^{8}$

All these opinions, however, shared as they may be, are rather marginal traits and the question of whether or not the nuclei of Descartes and Poussin's philosophical concepts have fundamental common aspects remains open. Kurt Badt ${ }^{39}$ has noted that the above similarities emerge as rather superficial.

In brief, the most essential differences can be summarized as follows: notwithstanding some elements of Stoic ethics (like the desire for tranquillity ${ }^{4^{\circ}}$ and a certain distance in relation to the world) Cartesian ethics are not Stoic because they eventually reveal themselves to be active and therefore in real opposition to Stoicism. It is no coincidence that Descartes's key words are verbs such as 'to direct', 'to influence' and 'to control'. ${ }^{41}$ For Descartes, passions, the central theme of Stoicism, are not weaknesses that must be suppressed but assets ${ }^{42}$ we have to learn to use properly. Passions in themselves are useful ${ }^{43}$ and we must only understand their causes, functions, meaning, advantages and drawbacks in order then to control, manage and guide them with the help of free will. This concept of free (because reasonable) will ${ }^{44}$ implies a separation between feelings and thoughts, a separation that renders conceivable the idea of a possible automatic conditioning of men, applicable mainly to men too weak to control their passions. ${ }^{45}$

Entirely the opposite holds true for Poussin. Such automatic conditioning is unthinkable to him for he assumes outright a direct link between thoughts and passion when, for instance, he expresses his desire to remind the viewer of wisdom and virtue as refuges from destiny in the depiction of the most agitated scenes. Imagining a type of 'AntiSacraments' in contradistinction to his paintings of the 'Seven Sacraments' painted for Cassiano Dal Pozzo and Paul Fréart de Chantelou, Poussin envisions a series of pictures representing episodes in which fortune does the oddest things to men, the idea being to teach the viewer to acquire wisdom and virtue and so remain firm and immobile against the vagaries of chance. ${ }^{4}$ As fortune is as unpredictable as it is irresponsible, it appears better to keep a tight rein on all passions and thus become totally independent. What is indicated here makes it difficult to maintain a parallelism between the philosophical concepts of Descartes and Poussin, let alone a possible influence of the philosopher on the painter of which, up to now, no trace has been found.

We will now look at the central issue of whether any indications exist of a procedural method common to both Descartes and Poussin. In Desjardins's 1904 Méthode the author hinted at such a similarity of approach when discussing the 'scientific discipline' and the 'secret and definite laws' of not only the philosopher and painter but also the playwright Corneille. Ten years later Grautoff was prepared to accept and develop this notion when he drew attention to the analogies between 'the principles according to which Descartes constructed his concept of the world', the structure of Corneille's plays and Poussin's paintings. ${ }^{47}$

Die Descartes verwandten Elemente haben Poussin aus seiner von einer Gesamtstimmung, einem rein künstlerischen Bewegungsmotiv ausgehenden Kunst der früheren Jahre fort in die rationalistische Atmosphäre der Hochrenaissance zurückgetrieben, und er korrigierte, innerlich immer wieder heimkehrend, ihre Ausdrucksformen an den [sic] Stil des Dramatikers Corneille. ${ }^{4^{8}}$

In 1949 Kenneth Clark pointed to the direction in which these analogies could be concretized in calling the painter the 'stern, Cartesian Poussin' who, in his opinion, aspired with his landscapes to give 'logical form even to the disorder of natural scenery' 49 - an opinion subsequently taken up by Walter Friedländer ${ }^{\circ}$ and Anthony Blunt. However, first 
of all it left a clear imprint on the concept René Huyghe presented in his 1960 book L'art et l'âme (figure 5), where by use of a kind of musical 'stretta' he tries to draw a parallel between Poussin and the philosopher. He insists that Poussin, like Descartes, based his art on reason and that, like Descartes, the painter looked at the world, but subjected the data he collected to a processing of the intellect. In so doing, just as Descartes had freed thought from the dominance of the Church, Huyghe insists Poussin achieved the same for painting. ${ }^{5}{ }^{1}$ With the exception of these last, disputable statements, Huyghe's thesis might well have appealed to Rensselaer W. Lee who in 1940 expressed the opinion that 'something closely akin to the Cartesian rationalism was strong in Poussin himself',,$^{2}$ as he doubtless had the same quotation as Huyghe in mind where Poussin theoretically distinguishes the superficial, exterior 'aspect' from the more profound 'prospect' from which the conclusion is drawn that the painter demonstrated the same scepticism regarding sensory perception as the philosopher. ${ }^{53}$ But these statements take no notice of the fact that Poussin's distinction between 'aspect' and 'prospect', clarified in a letter to Sublet de Noyers, ${ }^{54}$ has not only nothing to do with Cartesian scepticism (Poussin's distinction only concerns itself with how an uneducated glance at something differs from the way a judicious person looks upon the same object $)^{55}$ but is, above all, in no way Cartesian. The distinction is, in fact, medieval in origin and is to be found in the work of Alhazen, somebody whom we know Poussin studied and copied..$^{6}$

A similar objection applies to the references to 'clarté, which some authors would have unite Poussin and Descartes. Blunt feels the second series of the 'Seven Sacraments' features a 'clarity' corresponding to a society 'whose taste has been profoundly influenced by the methods of Descartes. ${ }^{57}$ Even if one could prove the profound Cartesian imprint on Parisian society in the 1640 s in general and in particular on the patron Chantelou, ${ }^{58}$ it has to be conceded that the notion of 'clarity' as a property of 'beauty' is to be found in Thomas Aquinas. ${ }^{59}$ Yet another example is to be found in a manuscript of Vincenzo Borghini's, which in ${ }_{15} 64$ declares 'clarity' as one of the aesthetic qualities. ${ }^{60}$

Mentioning authorities such as Alhazen, Thomas Aquinas and Borghini prepares the path for the next argument, which distinguishes Poussin from Descartes by demonstrating how each shows a different way of coming to terms with authorities and tradition. Poussin followed the classic path when quoting in his writings, and his paintings drew from traditional authorities, implementing ideal examples from Antiquity or Raphael for instance. However, we know that Descartes - for various reasons ${ }^{61}$ - nourished such a strong desire to be independent of precursors and philosophers of the past that not only did he refuse to quote from them but was in fact contemptuous of philology and history, castigating them as 'useless sciences. ${ }^{62}$ Precisely this contempt - which according to legend, was responsible for
Descartes being poisoned at the court of Queen Christina of Sweden by philologists in fear of their position ${ }^{63}$ - pits the philosopher against the painter Poussin whose entire artistic output virtually exclusively featured subject matter chock-full of biblical, mythological and historical scenes. ${ }^{64}$

To avoid continuing along this rocky path which rears up the moment one follows only vague associations, ${ }^{65}$ our efforts should turn perhaps to seeking clues which could verify a concrete reception of Descartes in Nicolas Poussin's paintings. In 1990 Felix Thürlemann claimed to have arrived at a more adequate understanding of the 'Israelites Gathering the Manna' (Paris, Louvre; figure 6) ${ }^{66}$ painted for Chantelou in 1639 , by interpreting it against the background of Descartes's treatise, Les passions de l'âme, considered by the author to be 'part of the seventeenth century's cultural assets'. ${ }^{67}$ The problem remains, however, that the painting was completed ten years prior to the publication of the 'Passions', making the task of proving a concrete bond between the two somewhat difficult - in view of this it is hardly surprising that Thürlemann had no desire to carry out such work.

Lee's attempt in 1940, however, is more articulate and consequently more convincing. ${ }^{68}$ His purpose is to demonstrate that the Cartesian principles expressed in the Discours (I637) are actively involved in both Poussin's 'Israelites' and the famous lecture Le Brun delivered on it in I667. Lee's interpretation rests on the fact that Le Brun demonstrated that all the figures in the painting were subordinated to the main theme ${ }^{69}$ which, for Lee, gave evidence that both Poussin and Le Brun were following the second and third rules of Descartes's Discours, i.e. setting forth the need to divide a complex thing into its elements and then proceeding from the simplest to the most complex..$^{70}$ Unfortunately, for Lee, application of such rules does not prove exclusively Cartesian method as it can be easily observed that Alberti's treatise, 'Della Pittura' (I436) sufficiently pre-empts it with these words: 'imprima tutti e corpi ad quielo si debbano muovere, ad che sia ordinata la storia ... et cosi ... tutto apartenga a hornare $o$ a insegniarti la storia ${ }^{7^{1}}$

As Baxandall has demonstrated, the technical concept of the 'composito' is broadly based on rhetorical models developed, amongst others, by Quintilian. ${ }^{72}$ It has been shown therefore that Descartes followed Quintilian when he developed his concept of clear and distinct ideas, ${ }^{73}$ and is interesting to note that it is through the person of that great Roman orator that Descartes and Poussin come together (at least in the ideal sense). Poussin himself had recourse to Quintilian's concepts: not only in his famous letter on 'modes' does he reveal a. direct relationship to 'Institutio Oratoria' ${ }^{74}$, but in a letter written in 1655 to Chantelou he paraphrased and even adapted a passage from the treatise for his explanation of the differentiation of the various talents of painters. ${ }^{75}$ Nine years earlier the artist had revealed how faithful a disciple of Quintilian he was when he refused a 


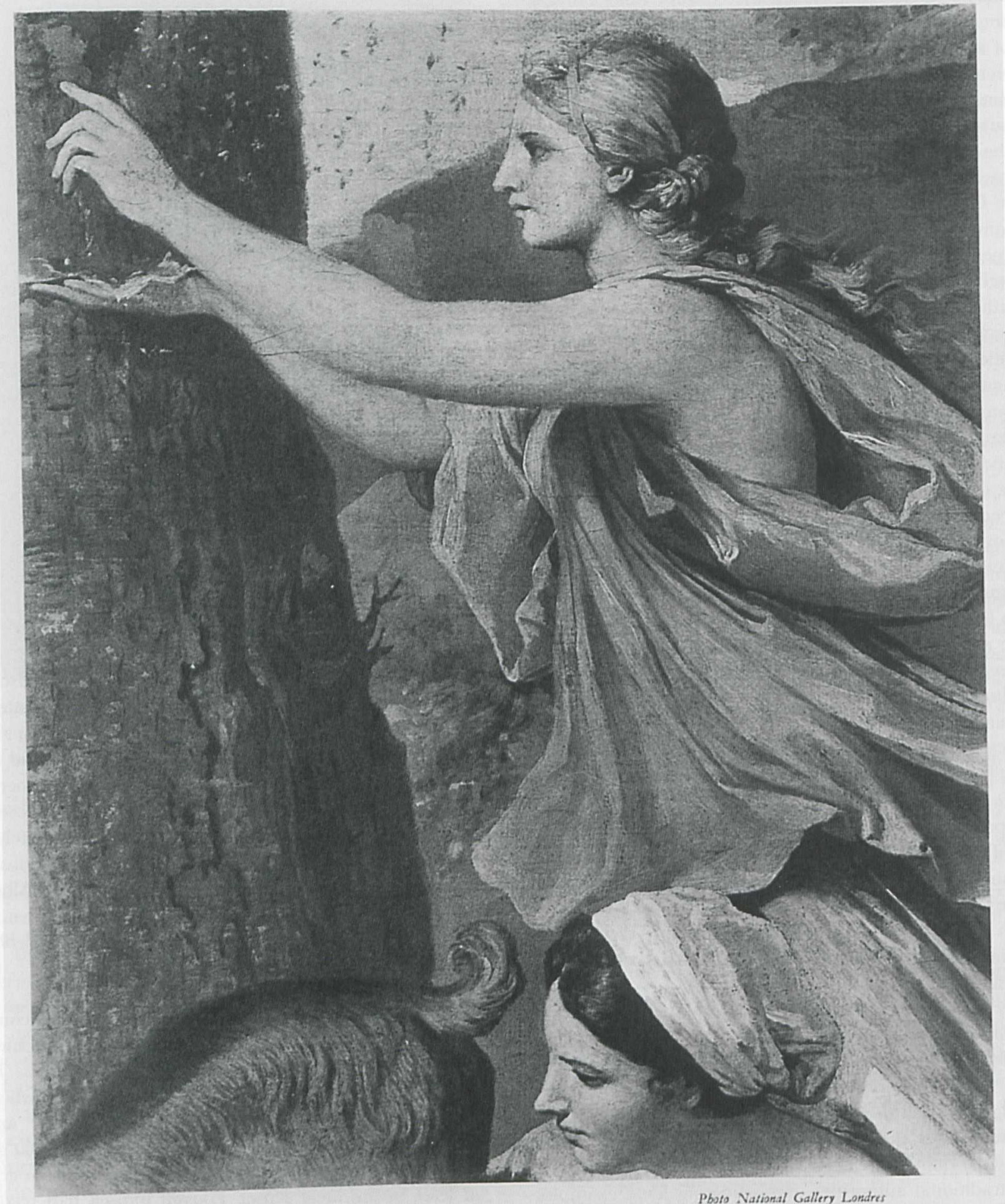

Le cartésianisme part de l'observation directe mais la régente mentalement : Poussin réalise le même équilibre. POUSSIN. I'ENFANCE DE JUPITER. (1637). Détail. Dulwich Collection. 


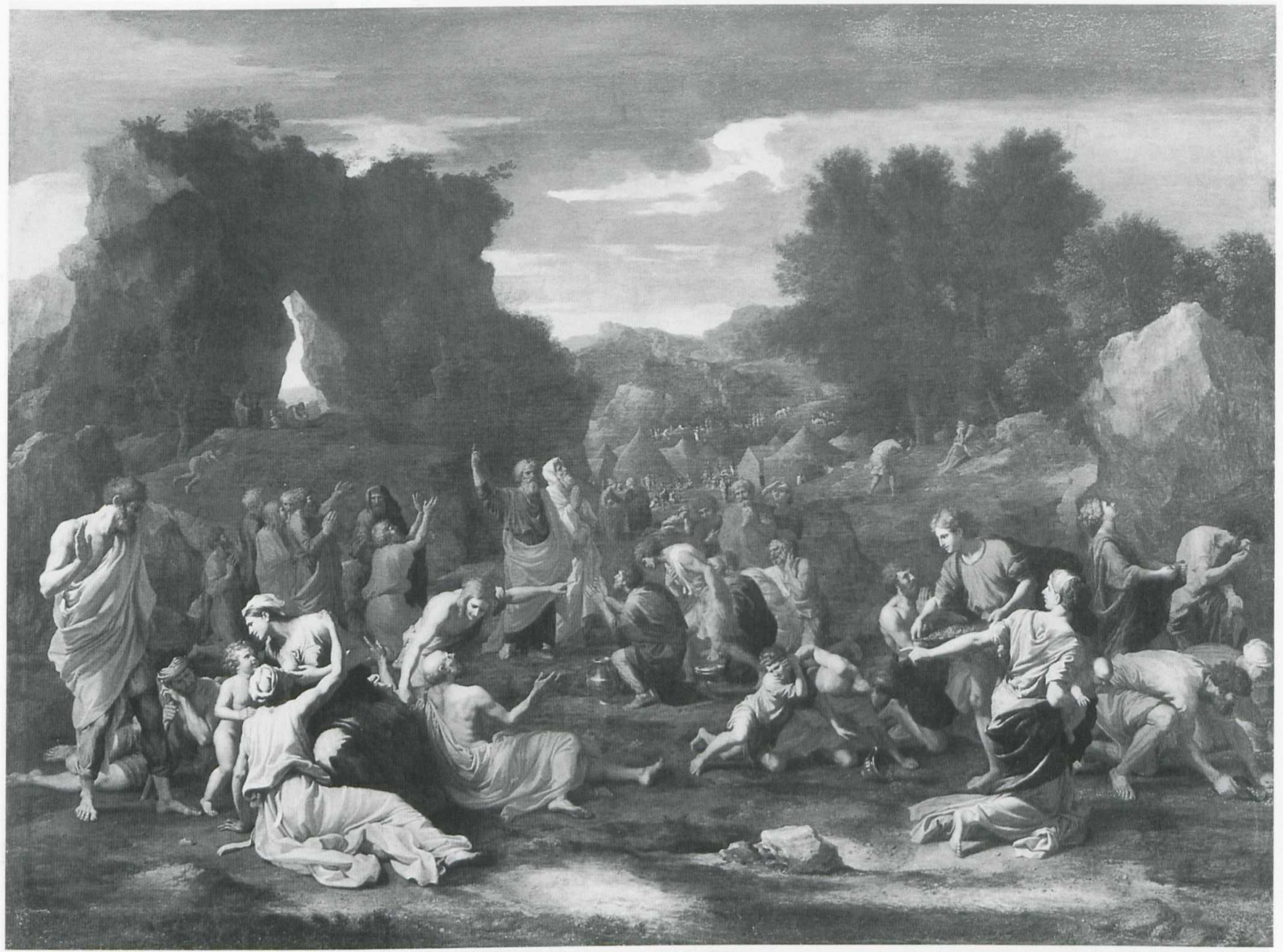

Figure 6. Nicolas Poussin, The Israelites Gathering the Manna. Paris, Louvre, I639.

commission to paint a 'Christ Bearing the Cross', basing his argument directly on a passage from the 'Institutio Oratoria', which advises the orator to identify himself with his subject in such a manner as to produce the mindset within himself to be utterly convincing:

Quare in iis, quae esse verisimilia volemus, simus ipsi similes eorum qui vere patiuntur adfectibus, et a tali animo proficiscatur oratio qualem facere iudiecem volet.... Primum est igitur, ut apud nos valeant ea quae valere apud iudicem volumus, adficiamurque antequam adficere conemur. ${ }^{76}$ Nos illi simus, quos gravia, indigna, tristia passos queremur, nec agamus rem quasi alienam, sed adsumamus parumper illum dolorem. Ita decemus, quae in nostro simili casu dicturi fuissemus. ${ }^{77}$

The painter declined the commission, saying that his precarious health would not permit him to throw himself into the kind of affliction necessary to realize a 'Christ Bearing the Cross', with these words written in 1646 to the client Jacques-Auguste de Thou:
Je n'ay plus assez de joye ni de santé pour m'engager dans ces sujets tristes.... Je ne pourrois pas résister aux pensées affligeantes et sérieuses dont il faut se remplir l'Esprit et le coeur pour réussir à ces sujets d'eux mesmes si tristes et lugubres. Dispensez m'en donc s'il vous plaist. ${ }^{78}$

However, Poussin's awareness and, above all, observance of Quintilian's rules should not be overestimated. Fumaroli correctly emphasized that the orator was not so closely followed when painting the 'Israelites Gathering the Manna'. The figure of Moses violates Quintilian's injunction never to raise one's arms or hands above the eyes. ${ }^{79}$

Although the painter and philosopher came together only indirectly in the application of Quintilian's concepts, within the French Academy we. find ourselves on much firmer ground.

In Charles Le Brun we have a person familiar with Descartes's writings, at least with the Passions ${ }^{80}$, which he tried to render applicable to painting by developing a close link between the passions described and analysed 
by Descartes and the representations following Poussin's statement:

... de mesme que les 24 lettres de l'alfabet servent à former nos parolles et exprimer nos pensées, de mesme les lineamens du corps humain à exprimer les diverses passions de l'ame pour faire paroistre au dehors ce que l'on a dans l'esprit. ${ }^{81}$

Thus Friedländer's observation defining the relationship between Poussin, Descartes and Le Brun was correct when he wrote:

A renewed interest in systems governing the emotions or passions prevailed in philosophic and artistic circles in France, culminating in the 'Traité des Passions' published in 1649 by René Descartes. Poussin's fame in the French Academy was largely the result of his special gift in portraying emotions. ${ }^{82}$

Hence, Poussin and Descartes's interest in 'passions' - one analysing them and explaining them, the other portraying them - was coincidence enough for the French Academy, mainly in Le Brun's lectures, to justify the connection. Now we have to ask ourselves if the idea of Poussin being influenced and conditioned by Descartes did not have its roots within the Academy and in Le Brun's 'Conférence sur l'expressions' in which Poussin's works are cited to illustrate Cartesian ideas as well as lectures by Le Brun or Bourdon (the latter, when we look at his portrait of the philosopher, must have had some knowledge of the man). The fact remains that Descartes's name was never explicitly associated with Poussin, although both Le Brun and Bourdon often availed themselves of the vocabulary and theories of the 'Passions' in an effort to explain certain details of the painted figures, which in this way could have their authenticity and correctness confirmed. In his 'Conference' (November i667) on Poussin's 'Israelites Gathering the Manna' Le Brun describes the man who is watching stupefied as he witnesses a woman nursing her own mother thus:

... les esprits qui abandonnent les autres parties de son corps, font qu'elles demeurent sans mouvement. ${ }^{83}$

This passage obviously owes its existence to the Cartesian treatise where, in article 73 , we read this about the effects of astonishment:

Et cette surprise a tant de pouvoir, pour faire que les esprits ... sont tellement occupés à conserver l'impression de l'objet qu'on admire, qu'il n'y en a aucuns qui passent de là dans les muscles ... ce qui fait que tout le corps demeure immobile comme une statue. ...84

In spite of the two academics' hesitation explicitly to name Descartes as Poussin's source here, at the beginning of the twentieth century first Desjardins and then Grautoff argue in favour of such a dependency. The French art historian wrote about the famous 'Rebecca and Eliazar' in I904:
Dans la 'Rébecca', les gestes des filles groupées autour la fontaine signifient, ici la curiosité, là l'envie, ici l'admiration, là l'indifférence : tout l'index du traité 'Des Passions de l'âme' de Descartes. ${ }^{85}$

His German colleague hypothesized that the painter would have known the Cartesian ideas of the human soul if not through Les Passions then via the Discours, the repercussions of which could be observed in some of Poussin's works:

Wir wissen nicht, ob Poussin Descartes [sic] Traktat über die Leidenschaften der Seele, der 1649 erschien, gekannt hat. Jedenfalls können wir aus dem Übergewicht des Rationalismus in seinen Formgedanken mit Sicherheit annehmen, dass er durch theoretische Studien zu dem maskenartigen Ausdruck von Affekten gelangte; und es liegt nahe, dass er zu Descartes, der ihm nicht fremd sein konnte, griff. Schon in dem 'Discours de la méthode' ist die Grundanschauung über die Leidenschaften der Seele enthalten, ... In der Tat korrespondiert der Ausdruck ritterlicher Großmut des Scipio Africanus, der Ausdruck der Ehrerbietung des Allutius auf der Enthaltsamkeit des Scipio den Definitionen des Descartes. ${ }^{86}$

The only problem is that, in spite of Grautoff's statement that the concept of the passions of the soul was already contained 'in nuce' in the Discours, Poussin would not have been able to find anything similar. Thus, eliminating the Discours published in 1637 , we are left with the Passions which was not to be published till $\mathrm{I} 649$, nine years too late to have influenced the compositions of the 'Continence of Scipio' (Moscow, Pushkin Museum of the Fine Arts) and the 'Scipio Africanus and the Pirates' (Windsor Castle, Royal Collection), chosen by Grautoff for proof of this impact, which were actually completed in 1640 and 1642 respectively. ${ }^{87}$

But even the Discours has to be discounted as a source for Poussin, not only because the 'jewel' of his representations of the passions (the desperate and terrorized face of the mother in the 'Massacre of the Innocents', Chantilly, Musée Condé: figure 7$)^{88}$ preceded the publication of the treatise by several years, but also because the actual physical source of the expression is well known, and, as one could expect of Poussin, based on an ancient mask. ${ }^{89}$ Studying his models - taken from antiquity, Raphael or other masters Poussin did not need Cartesian descriptions or definitions to paint these passions. The very field of art theory itself already contains the concept of the 'movement of the soul' or 'the passions of the soul' in Alberti's (I436) and Lomazzo's (1548) treatises, as elements requested to be represented by the painter..$^{90}$

The question of whether or not Poussin read the Discours and the Passions has also to be linked to the question of whether or not he was aware of Descartes's optical theories as propounded in the Dioptrique published alongside the Discours in 1637. Grautoff's idea that Poussin's reading of the Dioptrique represented an important step for his - as shown here, doubtful - knowledge of the Passions ${ }^{91}$ has been backed by a more recent attempt to render the hypothesis 


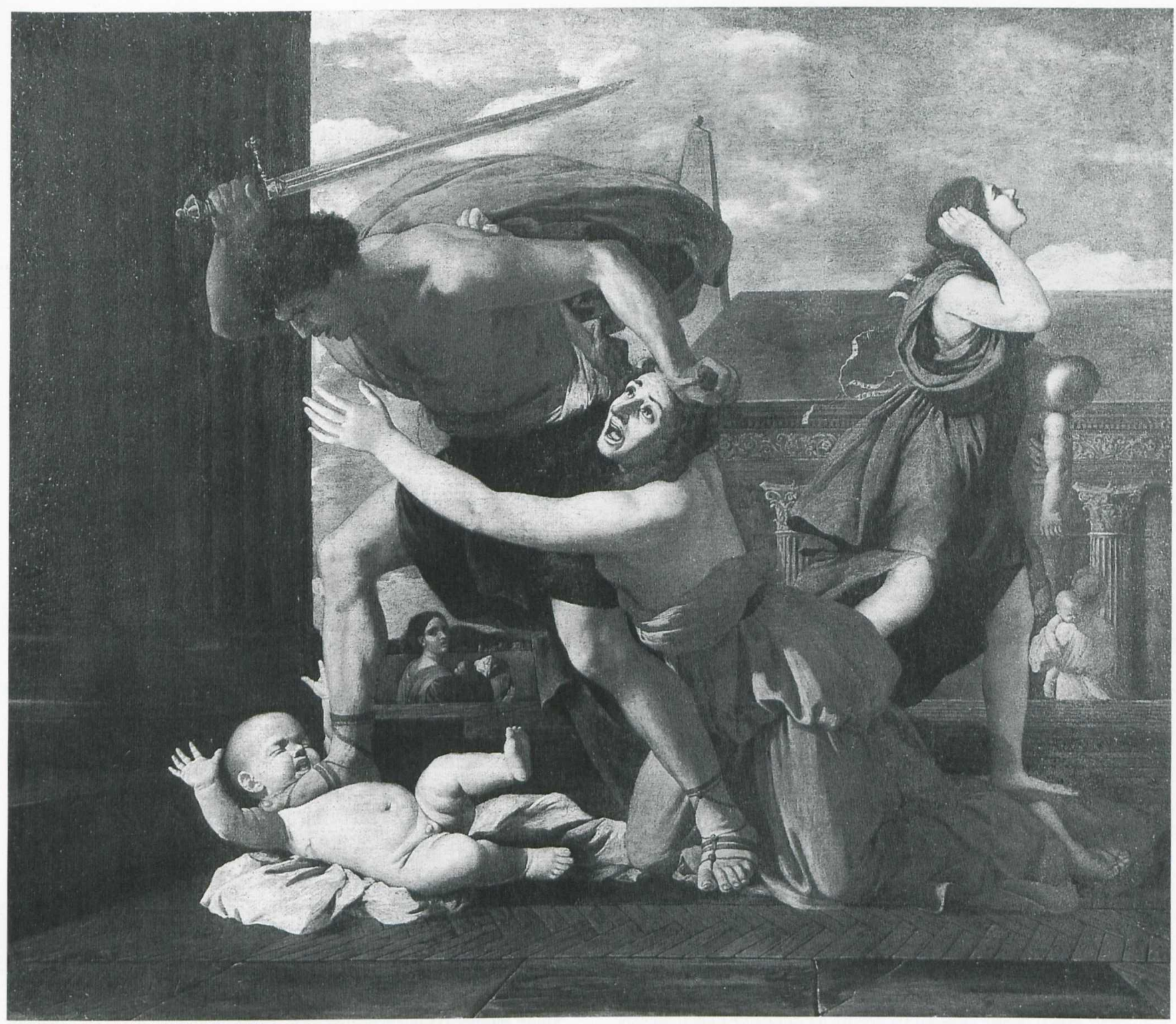

Figure 7. Nicolas Poussin, The Massacre of the Innocents. Chantilly, Musée Condé.

of Poussin's familiarity with the Dioptrique by Elizabeth Cropper in an interpretation of 'The Healing of the Blind Men at Jericho' painted in 1650 (Paris, Louvre: figure 8). Inspired by a proposal of Louis Marin,,$^{92}$ Cropper attempts to apply some elements of this Cartesian treatise to the painting. Under the suggestive title 'Toucher le Regard' (Touching the Gaze) she highlighted the bond between seeing and touching, evoked by the Cartesian metaphor of the blind man who sees with his hands thanks to his cane, ${ }^{93}$ feeling this could have influenced the painting's iconography. ${ }^{94}$ However, this hypothesis appears difficult to support, given the fact that the only precise element to tie the painting to Descartes's text is the cane, a highly traditional element in the portrayal of the blind, and the rest of the painting, if a faithful rendition of the biblical story, implements traditional iconography rather than Descartes. ${ }^{95}$ Another question to ask is what Poussin could have gained from reading Descartes's optical treatise, which did not set out to provide a complete theory of light, but instead furnished instructions for artisans, offering innovative methods for making new optical instruments and presenting a machine for cleaning lenses. ${ }^{96}$ Therefore the lack of all traces in Poussin's writings and drawings that could attest to some considerations of the Dioptrique, as has been proved for instance, regarding Alhazen and Leonardo da Vinci, comes as no surprise. ${ }^{97}$

Poussin's study of Alhazen's and Leonardo's theories simply demonstrates that the painter - along with other 


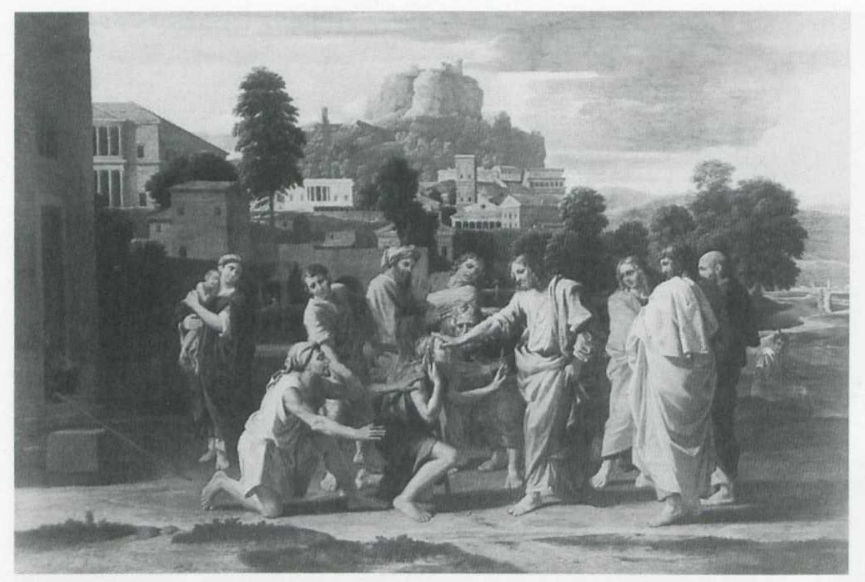

Figure 8. Nicolas Poussin, The Healing of the Blind Men at Jericho. Paris, Louvre, 1650 .

artists - wished to base his art on mathematical, geometric and scientific principles: a desire which does not automatically link him with Descartes. ${ }^{98}$ Those who maintain that in the 'Judgement of Solomon' (Paris, Louvre) Poussin reveals himself to be 'without doubt a follower of the Cartesian anthropological concept in which the essential centre of man is seen in this reason', simply because the artist chose a symmetrical composition featuring the protagonist in the middle, ${ }^{99}$ clearly ignore all the other paintings by Poussin in which the artist also adopted a centralized composition without touching on subjects that concern as with 'Solomon' - reason or knowledge. In the wake of this we could also maintain that Poussin had observed the Cartesian rules of analysing and enumerating when immediately upon his arrival in Rome, according to Bellori, he began measuring ancient statues to understand their proportions $^{\text {I0O }}$ - had this not occurred more than ten years prior to Descartes publishing his Discours! Were this to be taken seriously then we would have the disconcerting reversal of presenting Descartes, owing to Poussin's chronological precedence already noted in the field of the passions, identified as a disciple of Poussin. This absurd result should have us on our guard against such hasty conclusions. ${ }^{\text {IOI }}$

Our conclusion leads us to say that there exists no proof of any assimilation of Cartesian ideas by Nicolas Poussin. The only instance in which their works have been associated is within the French Academy when, concerning the passions of the soul, Poussin's pictorial representations are argued to have been in unity with Descartes's theoretical considerations. The example of Poussin, therefore, warns us of the pitfalls of the mere similarity of certain concepts, which result in being extremely misleading. On the other hand, there are gains to be made by such cases, as close examination of their anomalies is extremely helpful in better evaluating the routes and development of Cartesianism.
The very similarity of some concepts and modes of thinking of these two significant figures perhaps yields evidence suggesting that the circumstances were already suitable for an acceptance of Cartesian ideas, which collected, absorbed and unified some earlier trends. The fact that the 'all new science $^{102}$ of Descartes, with its direct recourse to human reason as the source of all true knowledge, aspired to accommodate and go beyond all other sciences means it should comes as no surprise when we encounter traces of such concepts which are also oriented toward an absolute rationality - an orientation perceivable in Nicolas Poussin's entire oeuvre. So, finally, it would be nothing other than that 'rationalisme autoritaire', generally deplored today as the most negative aspect of the 'esprit cartésien', cited in the opening quotation, that would be able to link the painter to the philosopher. This very 'authoritarian rationalism' causes the reception of Poussin and Descartes's work in the eighteenth and nineteenth centuries to suffer parallel fates, for even the painter's reputation suffered damage in this period owing to what was described as his excessive recourse to rationalism. Charles Perrault, one of the earliest of such critics, wrote:

Quelques-un le blamèrent d'avoir donné un peu trop dans la manière austère et précise. D'autres prétendent que ces deffauts ne sont autre chose que des beautez un peu trop grandes pour les yeux qui n'y sont pas accoustumez. ${ }^{103}$

In the final analysis this would concur once again with Descartes, of whom Nicolas de Malbranche said in his 'Recherche de la verité' that he would deserve the glory for having been the first to arrive where darkness impenetrable by the human eye appeared to reign. ${ }^{104}$

\section{NOTES}

This article is based on a lecture given during the International colloque 'Mutamenti culturali in Italia attorno al 1700', held in March 1999 at the Kunsthistorisches Institut in Florence. I am gratefully indebted to Frank Büttner (Munich) as well as to Volker Kapp (Kiel) for their helpful suggestions; heartfelt thanks also to James Rumball who skillfully revised the English text.

I - Pierre Guenancia, Descartes - Bien conduire sa raison (Paris, 1996).

2 - Rainer Specht, Descartes (Reinbek bei Hamburg, r966), p. 152.

3 - For Poussin's 'Self-Portrait' (Paris, Louvre) see Nicolas Poussin 1594-1665, exh. cat., Paris, 1994, p. 428, No. 190.

4 - See for example Walter Friedländer, Nicolas Poussin - A New Approach (London, 1966), p. 74 as well as, recently, Thomas Puttfarken, 'Poussin's thoughts on painting', in Commemorating Poussin - Reception and Interpretation of the Artist, eds Katie Scott and Genevieve Warwick (Cambridge, r999), pp. $53-75$, here p. 53 .

5 - For Bourdon's portrait see note I6 below.

6 - Thus, the statement voiced by Baigrie, according to whom 'with the exception of Meditation I... Descartes's writing are silent about art' seems to be erroneous; see Brian S. Baigrie, 'Descartes's Scientific Illustrations and "la grande mécanique de la nature", in Picturing Knowledge - Historical and Philosophical Problems Concerning the Use of Art in Science, ed. Brian S. Baigrie (Toronto, 1996), pp. 86-134, here p. 88.

7 - Oeuvres de Descartes, published by Charles Adam \& Paul Tannery, vol. vI (Paris, 1982): Discours de la méthode, p. 4 . 
8 - Descartes, Discours (note 7), p. 41: 'Mais, tout de mesme que les peintres, ne pouuant esgalement bien representer dans vn tableau plat toutes les diuerses faces d'vn cors solide, en choisissent vne des principales qu'ils mettent seule vers le iour, \& ombrageant les autres, ne les font paroistre qu'en tant qu'on les peut voir en la regardant'.

9 -Descartes, Discours (note 7), p. 113: 'Comme vous voyés que les tailledouces, n'estant faites que d'vn peu d'encre posée ça et là sur du papier, nous représentent des forets, des villes, des hommes, \& mesme des batailles $\&$ des tempestes, bien que, d'vne infinité de diuerses qualités qu'elles nous font conceuoir en ces objets, il n'y en ait aucune que la figure seule dont elles ayent proprement la ressemblance; \& encores est-ce vne ressemblance fort imparfaite, vû que sur vne superficie toute plate, elles nous représentent des cors diuersement releués \& enfoncés, \& que mesme, suiuant les regles de la perspectiue, souuent elles representent mieux des cercles par des ouales que par d'autres cercles; \& des quarrés par des lozanges que par d'autres quarrés; \& ainsi de toutes les autres figures.....

Io - For this engraving by Etienne Picart after Poussin's 'Plague at Ashdod' see Georges Wildenstein, Les graveurs de Poussin au xvme siècle (Paris, 1957), p. 133 , No. 24 .

II - Descartes, Discours (note 7), La Dioptrique: fifth discourse 'Des images qui se forment sur le fond de l'oeil', especially pp. 115, 117, 120 and 123. See also Elizabeth Cropper, 'Toucher le regard. Le Christ guérissant les aveugles et le discours de la peinture', in Nicolas Poussin (1594-1665), Actes du colloque, ed. Alain Mérot (Paris, 1995), vol. II, pp. 603-626, repeated in: Elizabeth Cropper and Charles Dempsey, Nicolas Poussin - Friendship and the Love of Painting (Princeton, 1996), p. 211.

12 - Oeuvres de Descartes, published by Charles Adam \& Paul Tannery (Paris, 1983), vol. vir: Meditationes de prima philosophia, p. 20 (Prima meditatione):

'... certe tamen ad minimum veri colores esse debent, ex quibus illud

componant'. Baigrie (note 6), p. 130, note 7 has directed attention to the fact that Descartes in his unfinished treatise La Recherche de la vérité par la lumière, published only in 170I, compares the correcting function of reason towards the imperfect senses to a painter, called in order to perfect the awkward sketch of a young disciple.

13 - Translated after Descartes, Discours (note 7), p. I8.

14 - Ibid.

I5 - Anthony Blunt, Art and Architecture in France 1500-1700 (The Pelican History of Art: London, 1980), p. 195: 'In philosophy it was the age of Descartes, ... in painting that of Poussin....' For Blunt's other opinions concerning the relation Descartes-Poussin see below, note 98 .

I6 - For the portrait, once attributed to Frans Hals (Paris, Louvre), today considered as a copy after the lost original see E. C. Montagni, L'opera completa di Frans Hals (Milan, 1974), p. 105, No. 173, where the canvas is discussed together with other similar paintings; see also Geneviève RodisLewis, catalogue de l'Exposition Descartes (Paris, 1987), No. I; Seymour Slive, Frans Hals (London, 1974), vol. 1, p. I64 and vol. III, p. 89, No. 175 instead identifies the original painting by Frans Hals with the version today conserved at the Statens Museum for Kunst at Copenhagen; for a similar opinion see Geneviève Rodis-Lewis, 'Sur quelques portraits de Descartes', in Regards sur l'art (Paris, 1993), pp. ${ }_{157-67}$, esp. p. 159 with a discussion of also the other Descartes portraits at Utrecht (signed by Jan Baptist Weenix: figure 4) and at Groningen (drawing by Jan Lievens); the portrait, today attributed to Sébastien Bourdon (Paris, Louvre: figure 2) but recently put in doubt again by Jacques Thuillier (see below), was once attributed to David Beck, Van Dyck's disciple and court painter of Queen Christina of Sweden who - according to a report - would have been 're-converted' to religious belief by Descartes while he was painting the philosopher in 1650 on the orders of Christina (see for this Specht, p. 137). Jacques Thuillier, Sébastien Bourdon: ${ }_{1616-I 67 I}$ (also exh. cat. Montpellier/Straßbourg; Paris, 2000), p. 489 , No. 150 stresses the fact that Bourdon only arrived at Stockholm in October 1652 when Descartes had already been dead for two years and therefore doubts the attribution to Bourdon - however, the portrait could also have been painted in 1644 or $1647-48$ while Descartes was in Paris, even though Rodis-Lewis, 'Sur quelques portraits', p. I6I, note II thinks that this hypothesis is 'peu vraisemblable' (yet, without giving any reason for this opinion). Another (until now unknown) portrait by Philippe de Champaigne has been reported by Bernard Dorival, Philippe de Champaigne (1602-1674) (Paris, 1976), vol. п, p. 374, no. 1984 and p. 166, no. 339, where also another canvas by this painter is discussed which had been erroneously identified as a portrait of Descartes. Finally, the lost portrait of Descartes has to be named, which had been drawn by Rembrandt and which was documented in the early Settecento in the collection of Valerius Röver at Delft. For Weenix's portrait from around $1647-49$ see Jennifer M. Kilian, entry 'Weenix, Jan Baptist', in The Dictionary of Art, ed. Jane Turner (London, 1996), vol. 33, p. 26.

17 - For these dates see e.g. the chronological table furnished by Stephen Gaukroger, Descartes - An Intellectual Biography (Oxford, 1997), p. Xv.

18 - For an interpretation of such a 'deracinated' life, 'supérieur aux petites patries, citoyen d'une République des Lettres universelle' (as Marc Fumaroli, L'École du silence [Paris, 1994], p. 6o puts it), as a French quality which unites Poussin and Descartes see André Gide, Poussin (series 'Les Demi-Dieux': Paris, 1945), (without pagination) p. 4, and Geneviève Rodis-Lewis, 'Descartes et Poussin', in: XVIIe siècle, 23, 1954, p. 521, then again in: idem, Regards sur l'art (Bibliothèque des Archives de Philosophe, Nouvelle Série 56: Paris, 1993), pp. 85-114 (the version cited here), p. 96. 19 - Gaukroger (note 17), p. XVII.

20 - For this letter see Charles Jouanny, 'Correspondance de Nicolas Poussin', in Archives de l'art frangais, vol. 5 (Paris, I9II), p. 132, note 2; a short comment is also given by Anthony Blunt, Nicolas Poussin (London, 1967), p. 21r. This encounter between Poussin and Gassendi at Paris had been doubtlessly favoured by the narrow contacts between the Roman patron of the painter, Cassiano Dal Pozzo, his friend Claude-François de Peiresc, Gassendi's patron, and Gassendi himself. See e.g. the correspondence by Dal Pozzo and Peiresc where Gassendi is named, collected in: Peiresc Lettres à Cassiano dal Pozzo (1626-1637), eds Jean-François Lhote and Danielle Joyal (Clermont-Ferrand, 1989), pp. 218, 244, 249, 257, and Anna Nicolò, Il carteggio di Cassiano dal Pozzo (Florence, 1991), p. 5, letter No. 82 (sent from Gassendi to Dal Pozzo I6 May I642). For Peiresc as Gassendi's patron and collaborator as well their correspondence see Barry Brundell, Pierre Gassendi (Dordrecht, 1987), passim, where reference is also made to the opposition between Descartes and Gassendi.

2I - Marc Fumaroli, L'École ... (note 18), p. 57: ' ... des grandes choses vagues ....

22 - As a matter of fact, the quotations by Fumaroli, L'École ... (note 18), p. 57 are exclusively taken from the preface of Desjardin's book where he is not dealing with Poussin in particular but is instead talking about the poet in general (Paul Desjardins, La Méthode des classiques français [Paris, 1904], p. II: .... le poète, une fois imprégné de la discipline scientifique, ne se permet point d'insérer son caprice dans la réalité...' resp. about the classical drama ('La comédie classique...; le réel, avec ses lois secrètes et sûres, affleure partout').

23 - For a chronologically neighbouring reception of this trio see e.g. Otto Grautoff, Nicolas Poussin - Sein Werk und sein Leben (Leipzig, 1914), p. 219: 'Was Poussins Werke von jenen Vorbildern [i.e.: Mantegna/Raffael] unterscheidet, ist wiederum sein Franzosentum. Neben der geistigen Verwandschaft mit Descartes, wird in dieser Epoche vor allem die mit Corneille deutlich.' For a (quite curious) attempt to deepen this connection between the painter and these playwrights see H. T. Barnwell, 'Some Notes on Poussin, Corneille, and Racine', Austratian Foumal of French Studies, 4/2 (1968), pp. ${ }^{149-61}$ where the fact is stressed that Poussin used a toy theatre in order to develop his compositions - for a critique of this argument see David Carrier, Poussin's Paintings - A Study in Art-Historical Methodology (Pennsylvania,1993), p. 72, note 97.

24 - Erwin Panofsky, 'Father Time', in Studies in Iconology - Humanistic Themes in the Art of the Renaissance (New York, $1965^{4}$; published for the first time in 1939), pp. 69-93, here p. 92. For an almost direct reception of this notion of Poussin's 'cartesian mind' see Samuel Holt Monk, 'A Grace 
Beyond the Reach of Art', Fournal of the History of Ideas, v (I944), pp. 13 $3^{1-50}$, esp. p. 138: 'So cartesian a mind as that of Nicholas [sic] Poussin....' 25 - Friedländer, Poussin (note 4), p. $74 \mathrm{~s}$.

26 - Friedländer, Poussin (note 4), p. 37. Perhaps Friedländer was thinking of notions about Poussin such as the lines written by Desjardins in his monograph on Poussin, Paris 1903, p. 103 about the everyday life of the painter, who - in Desjardin's view - would not let himself be swayed either by the passions or by chance but always controlled himself.

27 - Descartes, Discours (note 7), p. 9 s.

28 - Jouanny (note 20), p. 235, letter No. 96 to Chantelou from 2 I

December 1643: 'Il est bien vrai que vous êtes en une école là où l'on peut apprendre à devenir sage. Vous avez le grand livre ouvert où l'on voit....' 29 - See e.g. Michel de Montaigne, Essais, ed. Alexandre Micha (Paris, 1969), Livre I, Chapter xxvi: De l'institution des enfans', p. 205: 'Ce grand monde je veux ce soit le livre de mon escholier', as opposed to (p. 200) the 'facheuse suffisance ... pure livresque'. It is interesting to observe that Montaigne some lines earlier talks about this world in terms taken from the art of painting (p. 205): 'Mais qui se presente, comme dans un tableau, cette grande image de nostre mere nature en son entiere magesté.... For the indication of Montaigne as Descartes's source for metaphor as well as for other citations see Samuel S. de Sacy, Descartes (Paris, 1996; published for the first time in 1956), p. 24 and Léon Brunschvicg, Descartes et Pascal lecteurs de Montaigne (Neuchatel, 1945), p. 99, 127 and, above all, p. 106. For the use of the image of the 'great book of the world' also by personalities such as William Harvey, Paracelsus, Galilei and Boyle see Steven Shapin, Die wissenschaftliche Revolution (Frankfurt/Main, 1998), p. 84. For the tracking of this metaphor down to St Augustine see ibid., p. 94, note 22, but it has to be remembered that also a contemporary of Descartes such as Dom Robert Desgabets already saw St Augustine as the source for this image: see his letters cited by Pierre Chaunu, Europäische Kultur im Zeitalter des Barock (Frankfurt/Main, 1989), p. $5^{83}$.

30 - See Epiktet, Encheiridion, ed. Kurt Steinmann (Stuttgart, I992), p. 24, note $19, \S$ I7: 'Life is a play'.

$3^{\mathrm{I}}$ - Descartes, Discours (note 7), p. 100.

$3^{2}$ - Jouanny (note 20), p. 235, letter No. 96 to Chantelou from 2I December i643. For an assessment of Poussin's stoicism in the context of the violence experienced in his century see Henry Keazor, " Je n'ay plus assez de joye ni de santé pour m'engager dans ces sujets tristes" Gewaltdarstellungen bei Nicolas Poussin vor und nach 1648', in Ein Schauplatz herber Angst - Wahmehmung und Darstellung von Gewalt im 17. fahrhundert, ed. Markus Neumann/Dirk Niefanger (Göttingen, 1997), pp. $170-87$.

33 - For this painting from $c$. 1647 see note 16.

34 - Jouanny (note 20), p. 26o, letter to Chantelou from 8 April I644.

35 - Descartes, Discours (note 7), p. 28.

36 - Rodis-Lewis, 'Descartes et Poussin' (note 18), p. 95.

37 - Descartes, Discours (note 7), p. 15.

38 - Jouanny (note 20), p. I22: letter No. 56 to Chantelou from 20 March 1642; though Poussin writes relative to 'perfect things' ('Les choses esquelles il y a de la perfection', i.e. his paintings) while Descartes applies to conclusions in general.

39 - Kurt Badt, Nicolas Poussin (Cologne, 1969), p. 72.

40 - Oeuvres de Descartes, published by Charles Adam and Paul Tannery, vol. XI (Paris, 1986): Les Passions de l'ame, p. 441, article 148.

$4 \mathrm{I}$ - Descartes, Les Passions (note 40), p. 370, article 50: ' $\ldots$ acquerir un empire tres-absolu sur toutes leurs passions...'; p. 230, article 212: ' . . s'en rendre tellement maistre, \& à les ménager...'

42 - Descartes, Les Passions (note 40), p.488, article 211: 'Car nous voyons qu'elles sont toutes bonnes de leur nature... '. See also Gaukroger (note 17), p. 18 who underlines the opposition between the concepts of the passions in the Stoicism ("the relation between the intellect and the passions ... one of straightforward conflict, so that the passions will only ever act to pervert judgement') and in the Cartesianism ('the passions and the emotions play a role in effecting actions').
43 - Descartes, Les Passions (note 40), p. 372, article 52.

44 - Descartes, Les Passions (note 40), p. I25, article 4r: 'Mais la volonté est tellement libre de sa nature, qu'elle ne peut jamais estre contrainte....

45 - Descartes, Les Passions (note 40), p. 133, article 50.

46 - For a description of this project, apparently never realized, see the letter from 22 June 1648 , written to Paul Fréart de Chantelou: Jouanny (note 20), p. 384, letter No. 162. For this see also Richard Verdi, 'Poussin and the "Tricks of Fortune", Burlington Magazine, cxxiv/956 (1982),

pp. 681-5. Descartes's concept seems similar to Poussin's vision of fate when the philosopher talks about it as if it were a person, writing in a letter to Chanut on 31 March 1649: 'Il semble que la fortune est jalouse de ce que je n'ai jamais rien voulu attendre d'elle, et que j'ai tâché de conduire ma vie en telle sorte qu'elle n'eût sur moi aucun pouvoir; car elle ne manque jamais de me désobliger, sitôt qu'elle en peut avoir quelque occasion.'

47 - Grautoff, Nicolas Poussin (note 23), p. 221: '... den Prinzipien, nach denen Descartes sein Weltbild geformt hat. ..'; ‘. . Struktur des Aufbaus in Corneilles Peripetie und in Poussins Kompositionen'.

48 - Grautoff, Nicolas Poussin (note 23), p. 22 I.

49 - Kenneth Clark, Landscape into Art (London, 1949), p. 65.

50 - Friedländer, Poussin (note 4), p. 37: 'The restraint in Poussin's pictures is in some respects parallel to that in the plays of Corneille, and to the structure of Descartes' logic.'

$5^{\mathrm{I}}$ - René Huyghe, L'art et l'âme (Paris, 1960), p. 196.

52 - Rensselaer W. Lee, 'Ut picura poesis: the humanistic theory of painting', Art Bulletin, xxII (1940), pp. 197-269, esp. p. 225.

53 - Lee (note 52), p. 225: ' ... Poussin .... like Descartes, distrusted the mirage of sense perception'. Huyghes, L'art ... (note 5I), p. I96: 'Il se refuse tout autant à se laisser dominer par l'experiénce visuelle, et il distingue soigneusement "l'aspect" du "prospect", qui dépend de la pensée.' RodisLewis, 'Descartes et Poussin' (note I8), p. 89: 'Au lieu de "se laisser prendre par les choses", il soumet leur "aspect" sensible au "prospect" qui est "office de raison"...'.

54 - Jouanny (note 20), p. 143, No. 61, undated letter to Sublet de Noyers: 'Il faut sçavoir ... qu'il y a deux manières de voir les objets, l'une en les voyant simplement, et l'autre en les considérant avec attention. Voir simplement n'est autre chose que recevoir naturellement dans l'oeil la forme et la ressemblance de la chose vûe. Mais voir un objet en le considérant, c'est qu'outre la simple et naturelle réception de la forme dans l'oeil, l'on cherche avec une application particulière les moyens de bien connoîstre ce mesme objet: Ainsi on peut dire que le simple aspect est une opération naturelle, et que ce je nomme le Prospect est un office de raison qui dépend de trois choses, sçavoir de l'oeil, du rayon visuel, et de la distance de l'oeil à l'objet. ...'

55 - Poussin's text on the distinction between 'aspect' and 'prospect' is always cited out of context: as a matter of fact, these lines are not part of a treatise, but part of a letter to Sublet de Noyers in which Poussin is defending himself against accusations that he would have deformed the decoration of the 'Grande Galerie' by inserting senseless changes. In order to admonish de Noyers that such incriminations could have been voiced by people, actually injudiciously concerning the matter discussed, Poussin introduces this distinction, concluding with the very clear assertion: '.. c'est de cette connaissance dont il serait à souhaiter que ceux qui se mêlent de donner leur jugement fussent bien instruits'. For a critical evaluation of this text from an art-theoretical viewpoint see also Carl Goldstein, 'The Meaning of Poussin's Letter to De Noyers', Burlington Magazine, CVIII (I966), I, pp. 2339 as well as Matthias Bruhn, Nicolas Poussin - Bilder und Briefe (Berlin, 2000), p. 40.

$5^{6}$ - For the reference to Alhazen as the source for Poussin see Anthony Blunt, Nicolas Poussin - Lettres et propos sur l'art (Paris, I989), p. 73, note 42. For Poussin's study of Alhazen see the biography by Félibien, commented by Claire Pace, Fétibien's Life of Poussin (London, 1981), p. 153, note 16.3. A similiar distinction between the 'exterior eye' and the 'eye of the intellect' can be found in the treatise by Giovan Battista Armenini, De' veri precetti della pittura libri tre (Ravenna, I586; cited here the edition by Stefano Ticozzi, 
Milan 1820), p. 22 where the author distinguishes the 'occhio esteriore' (which can be dazzled by beautiful colours) and the 'occhio dell'intelletto' (which, illuminated by precepts, looks deeper and recognizes the truth in every thing).

57 - Anthony Blunt, Nicolas Poussin (London, 1967), p. 257. For a completely different vision of the roots of this predilection for 'clarté', explaining it rather in the context of contemporary literature, see Alain Mérot,

'L'atticisme parisien: réflexions sur un style', in Eloge de la clarté. Un courant artistique au temps de Mazarin 1640-1660, exh. cat. (Paris, 1998), pp. 13-40. However, here too (p. 34) the French painting of the time of Mazarin is presented as striving 'à la suite de Descartes' for a clear distinction of the visual forms.

$5^{8}$ - Nevertheless, the fact has to be stressed that around twenty years later Chantelou's brother, Fréart de Chambray, in his book L'Idée de la perfection de la peinture, published in $\mathrm{I} 662$, shows a certain affinity to some Cartesian principles, evidenced also by Rodis-Lewis, 'Descartes et Poussin' (note I8), p. 93 ss.

59 - 'Claritas', seen together with 'integritas', the 'proportio' and the 'consonantia' as elements of Beauty. For the sources of these notions in the writings of Thomas Aquinas as well as in the treatise 'De pulchro et bono', erroneously attributed to him for a long time (as a matter of fact a section from the comment by Albertus Magnus concerning Dionysius Areopagita) see Maurice de Wulf, 'Les théories esthétiques propres à saint Thomas', in Revue néo-scolastique, II/6 (1895), pp. I88-205 (here esp. p. 194), II/8, pp. 34I57 (here esp. pp. 344 and $346-54$ ) and (by the same author) 'L'histoire de l'esthétique et ses grandes orientations', in Revue néo-scolastique, xvi (1909), pp. 237-59 (here esp. p. 245s.) and Erwin Panofsky, Idea (Berlin, 1960), p. 82, note 68 .

60 - See Vincenzio Borghini, Da una 'Selva di notizie' (manuscript today conserved at the Kunsthistorisches Institut in Florenz, No. K 783, [16 numero d'inventario 60765), xı: 'La "Somma della disputà", in Benedetto Varchi/Vincenzio Borghini, Pittura e Scultura nel Cinquecento, ed. Paola Barocchi (Livorno, 1997), p. I33. Also the apparent similarity between Descartes's statement on music, 'finis ut delectat', and the one by Poussin on painting, 'sa fin est la délectation', stressed by Rodis-Lewis, 'Descartes et Poussin' (note 18), p. 99, is actually based on views already expressed e.g. by Thomas Aquinas (see again Rodis-Lewis, 'Descartes et Poussin' [note 18], p. I0o). In this rather general wake also the frequently cited statement by Poussin has to be located to which Huyghe, L'art ... (note ${ }^{\mathrm{I}}$ ), p. 196 and Rodis-Lewis, 'Descartes et Poussin' (note 18), p. 89 are referring:

'Mon naturel me contrainct de chercher et aimer les choses bien ordonnées fuians la confusion qui m'est ausi contraire et anemie comme est la lumière des obscurs ténèbres.' In this case, too, the context of this sentence is always ignored - in fact, in this letter from 7 April I642 (Jouanny [note 20], p. 134s., No. 59) to Chantelou, from which these lines are taken, Poussin laments about the too numerous commissions imposed on him by the French court, drifting him to 'confusion'. A similiar reserve is valid for Poussin's critique of impatience and hurry, compared - see note 38 with similar remarks by Descartes in Rodis-Lewis, 'Descartes et Poussin' (note 18), p. 95.

$6 \mathrm{r}$ - As Specht, Descartes (note 2), pp. 37 and 4I, explained, on one hand this refusal was a provocation of the authorities; on the other hand in this way the philosopher avoided a direct confrontation. A major motivation, however, was doubtlessly rooted in the concept of Cartesianism itself, which nourished doubts and scepticism against all second-hand knowledge. Exactly this concept had been related by Friedländer, Poussin (note 4), p. 34 to Poussin's words 'Je n'ai rien négligé'. Friedländer compared it with Descartes's instruction to never accept anything wrong and to strive always after a knowledge of all things (from the Régles pour la direction de l'esprit [1628], trad. and ed. J. Sirven [Paris, I990], Règle rv, p. rg: ' ... ne mettre assurément rien de faux à la place du vrai et parvenir à la connaissance de tout...') - as shown above in the main text, Poussin and Descartes always took different ways to accomplish this rule, the painter by using what tradition offered, the philosopher by refusing it. Likewise, Kurt Badt,
'Je n'ai rien négligé', in Festschrift für Werner Gross zu seinem 65. Geburtstag am 25.11.1966, eds Kurt Badt and Martin Gosebruch (Munich, 1968), pp. $195^{-215}$ and then John Berger, 'Et in Arcadia Ego, Poussin', in The Moment of Cubism and Other Essays (London, 1969), pp. 81-5 have tried to construct a relation between the principles of Descartes's' philosophy and Poussin's words: Badt, p. 200, quoting Dilthey, is relating them only in a very vague way to Descartes's' rational aesthetics while Berger interprets them as the manifestation of an anxiety which urges Poussin to control his art and his paintings totally and which - in his interpretation - could be associated with the Cartesian doubt. The result of this anxiety in the fields of Poussin (art) and Descartes (science/nature) would be always the same: order and control. For a very astute critique of this very vague and associative connection see Carrier, Poussin's Paintings (note 23), p. 59 f. 62 - For this disdain and an interpretation of Cartesianism as a historiophobe concept on principle see Specht, Descartes (note 2), p. 79 and p. 137.

63 - For this legend based on rumours going around in Stockholm immediately after the death of Descartes see the biography by Charles Adam, Vie et Deurres de Descartes - Etude historique, published as vol. xin of the Oeuvres de Descartes, eds Charles Adam and Paul Tannery (Paris, 1910), p. 542 and Specht, Descartes (note 2), p. 80.

64 - The only exceptions are Poussin's two self-portraits, today in Paris and Berlin. Concerning this difference between Poussin and Descartes see also briefly Rodis-Lewis, 'Descartes et Poussin' (note I8), p. 99 as well as the severe condemnation by André Berne-Joffroy, 'Poussin e noi', Paragone,

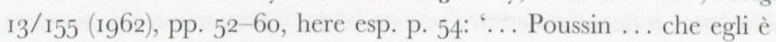
stato "il Descartes della Pittura". Come si è potuto senza sollevare una generale ilarità, diffondere una tale sciocchezza? È vero che Poussin ... è contemporaneo di Descartes ... Ma ognun vede come difficilmente potrebbero riscontrarsi due nature più differenti, sicché bisogna avere un'idea ben vaga e dell'uno e dell'altro, per credere di dire qualcosa appaiando i loro nomi. Descartes è l'uomo che decide ... di cavarsela da solo, senza lasciarsi ingarbugliare dal sentimento e dai dogmi altrui ... Tutt'altro temperamento quello di Poussin; egli studia con fervore Raffaello, Tiziano e sopratutto le sculture antiche... egli passa la vita a consultare la Bibbia e Aristotele....

65 - Two authors which have to be quoted here in this context are Berger and Stanic: Berger (note 6r), without giving further arguments, interprets the inscription on the tomb as an expression of Cartesian doubt while Milovan Stanic, Poussin - Beauté de l'énigme (Paris, 1994), p. 46 asserts a connection between the methods of Poussin and Descartes, constructed (according to Stanic) by a common 'ethic' element which is not further specified by him. I fail to see any definite connections to Poussin in the following compiled quotations from Cartesian writings on page 47 . 66 - For the painting see Nicolas Poussin 1594-1665, exh. cat. (note 3), p. 262 ss., No. 78 .

67 - Felix Thürlemann, Vom Bild zum Raum (Cologne, 1990), pp. 119-2I; for the quotation ('des kulturellen Wissenschatzes des 17 . Jahrhunderts'): p. II 3 . 68 - Lee (note 52), p. 223ss,

69 - See André Félibien, Conférences de l'Académie royale de peinture et de sculpture pendant l'année 1667 (Paris, I669), p. 83 and the edition of this lecture furnished in: Wilhelm Schlink, Ein Bild ist kein Tatsachenbericht - Le Bruns Akademierede von I667 über Poussin 'Mannazunder' (Freiburg i. Br., 1996), pp. $9^{-27}$, here p. 13: 'Que les groupes sont formés de l'assemblage de plusieurs figures jointes les unes aux autres qui ne séparent point le sujet principal, mais au contraire qui servent à le lier... Félibien, p. 9o/Schlink, p. I7: 'Il montra d'abord que M. Poussin a rendu toutes ses figures si propres à son sujet, qu'il n'y en a pas une dont l'action n'ait rapport à l'état où éstoit alors le peuple Juif. ..' And again Félibien, p. 94/Schlink, p. 20: '... Il a fait que toutes leus diverses actions et leurs expressions différentes ont des causes particulières qui se rapportent à son principal sujet.'

70 - Descartes, Discours (note 7), p. 18; Lee (note 52), p. 223 ss. 
71 - Leon Battista Alberti, Della Pictura, in Kleinere kunsttheoretische Schriften, ed. Hubert Janitschek (Quellenschriften für Kunstgeschichte und

Kunsttechnik des Mittelalters und der Renaissance, vol. II; Vienna, 1877), p. 123.

72 - See Michael Baxandall, Giotto and the Orators (Oxford, 1971), ch. III and - as a summary - Hans Körner, Auf der Suche nach der 'wahren Einheit'

(Munich, 1988), p. 14 .

73 - For Descartes's ambiguous attitude towards rhetoric see Gaukroger (note 17), p. 50 who in view of the apparent refusal of rhetoric in the Discours pleads for a rather cautious judgement: 'we should be very cautious indeed about attributing to him a straightforward dismissal of rhetoric'. For Quintilian as a source of inspiration for the Cartesian concept of clear and distinct ideas see Gaukroger (note 17), pp. 51, 119-24 and p. 182. 74 - Alain Mérot in Nicolas Poussin 1594-1665, exh. cat. (note 3), p. 83. 75 - See for the letter (reported also by André Félibien, Entretiens sur les vies et sur les ouvrages des plus excellens peintres anciens et modernes [Trevoux, I725], vol. Iv, p. 65): Jouanny (note 20), p. 433 ss., No. 194 (letter from 7 June 1655). For Quintilian as a source see Quintilian, Institutio Oratoria, xI/ 10 (\$§ 3, 6, 7, 8). Jouanny (note 20), p. 434, note I had already (incited by a suggestion by Alexis Pitou) referred to this source (however, indicating erroneously also $\S 5$ of the Quintilian text which Poussin did not copy), followed (even though without mentioning Jouanny's preceding reference) by Claire Pace, Félibien's Life ... (note 56), p. I6o, note 65.I.

76 - Quintilian, Institutio Oratoria, vI, 2, 27 e 28.

77 - Quintilian, Institutio Oratoria, vi, 2, 34 .

78 - The letter is documented in a section of the 'Discours sur les ouvrages des plus excellens peintres' (c, I695) by Loménie de Brienne which is quoted here according to the 'Corpus Pussinianum', collected and presented by Jacques Thuillier, Nicolas Poussin (Paris, 1994), p. 203. On the general context of Poussin's refusal to finish the 'Christ bearing the Cross' see Keazor (note 32 ), p. $170-87$.

79 - Fumaroli, L'École ... (note 18), p. I65.

80 - For the precise demonstration of Descartes's' writings as the sources see Jennifer Montagu, The Expression of the Passions (London, 1994), p. 156. Concerning the accusation of Le Brun for having plagiarized his treatise from the 'Art de connaître les hommes et le caractère des passions' di Marin Cureau de la Chambre (r649) see André Fontaine, Les doctrines d'art en France (Paris, I909), p. 69 and p. I02. For another influence of Descartes on the art theory of the French Academy (rejecting colour as a dangerous and wrong way leading away from truth because colour - unlike the extension - was not considered to be a real quality of corporeal things) see Christopher Allen, La Tradition du classicisme, PhD dissertation (University of Sydney, 1990), pp. 264-72.

81 - Reported by André Félibien, Journal, 26 February i648, fol. 43, quoted here according to Jacques Thuillier, 'Pour un "Corpus Pussinianum"', in Actes du colloque Nicolas Poussin, ed. André Chastel (Paris, I960), 2 vols, vol. II, p. 8 .

82 - Friedländer, Poussin (note 4), p. 36. For another attempt to untie this knot Poussin/Descartes/Le Brun see also the hints by Carrier, Poussin's Paintings (note 23), p. 72f., note 99 .

83 - Félibien (note 69), p. 92; Schlink (note 69), p. 18.

84 - Descartes, Passions (note 40), p. 144, article 73. In his lecture on the 'Christ Healing the Blind Men at Jericho' Bourdon makes an even more detailed reference to this Cartesian model when he describes the movements of the blind men and those of the man standing behind the arm of Christ - see Félibien, Conferences (note 69), p. 127. These detailed descriptions of surprised and astonished persons, using Cartesian terms, should be compared with the statement by Louis Marin, Détruire la peinture (Paris, 1997), p. go that the woman on the right of the painting 'Et in Arcadia Ego' (Paris, Louvre) would communicate the impression of a 'Cartesian admiration' ('...de traits qui m'évoquent cette passion d'admiration que Descartes analyse dans son Traité...).

85 - Desjardins, La Méthode... (note 22), p. 228.

86 - Grautoff (note 23), p. 221.
87 - For the 'Scipio' painting see Nicolas Poussin $1_{594}-1665$, exh. cat. (note 3), p. 29oss., No. 96; for the 'Pirate' drawings see Martin Clayton, Poussin Works on Paper (London, 1995), p. 152ss., nos 51/52. What applies to Grautoff's ideas on the impact of Descartes's' theories on Poussin's 'Scipio' compositions is also true for his theory that Poussin would have read Descartes's Principia philosophiae in order to develop his way to depict the passions of the soul because the text was published only in $1644-$ moreover, given Poussin's merely modest knowledge of the Latin language, he would even have to wait for the French edition of 1647 ; for Grautoff's statement ("Und hatte er die "Prinzipien" gut in sich aufgenommen, die den Schlüssel zum die Leidenschaften enthalten, so brauchte er nur die hier gefundene Methode auf die Analyse der Leidenschaften anzuwenden, um zu ähnlichen Resultaten zu gelangen wie Descartes selbst.') see Grautoff (note 23), p. 221. For Poussin's Latin see Henry Bardon 'Poussin et la litterature latine', in Actes du colloque Nicolas Poussin (note 81), vol. I, p. $123-132$.

88 - For this painting see Nicolas Poussin - La collection du musée Condé à Chantilly, exh. cat. (Paris, 1994), p. $44^{\text {ss., No. } 3 .}$

89 - Rudolf Wittkower, 'The Role of Classical Models in Bernini's and Poussin's preparatory Works', in idem, Studies in Western Art (Princeton, NJ, 1963), vol. III, pp. 41-50; for this source see also Rodis-Lewis, 'Descartes et Poussin' (note 18), p. I07. For the suggestions concerning the sources for the mother on the right in the background of the painting see Wittkower, p. 106 (sarcophagus with Medea scenes) and Oskar Bätschmann, Nicolas Poussin - Dialectics of Painting (London, 1990), p. 22 (sculpture of a Niobid). 90 - In his treatise Lomazzo talks about the 'moti interni' and the 'passioni de loro animi', while Alberti calls them 'movimenti dello animo' - see Giovanni Paolo Lomazzo, Trattato dell'arte della pittura, scoltura et architettura, in Scritti sulle arti, ed. Roberto Paolo Ciardi (Florence, 1974), vol. II, p. $9^{8}$ and Alberti, Della Pictura (note 71), p. 12I.

9I - Grautoff (note 23), p. 453, note 229: 'Da Poussin schon in seinen ersten römischen Jahren durch Alhazan in die Dioptrik eingeführt wurde, liegt es sehr nahe, daß er auch Descartes' Dioptrik gelesen hat und von dort zu "Des passions de l'âme" gelangte.'

92 - Louis Marin, Détruire... (note 84), p. 74 and idem, 'Mimésis et description. Ou de la curiosité à la méthode de l'âge de Montaigne à celui de Descartes', in Documentary Culture - Florence and Rome from Grand-Duke Ferdinand I to Pope Alexander VII, eds Elizabeth Cropper, Giovanna Perini and Francesco Solinas (Bologna, 1992), pp. 23-47, here p. 46.

93 - Descartes, Discours (note 7), p. 184: '... ceus qui, estant nés aueugles, ... voyent des mains, ou que leur baston est l'organe de quelque sixieme sens, qui leur a esté donné au defaut de la de de la veüe.'

94 - See Elizabeth Cropper, 'Toucher le regard' (note II), p. 616 and Cropper and Dempsey (note II), p. 2 II.

95 - Also the fact that Christ is touching the eyes of the blind men in order to heal them is already furnished by the Gospel of St Matthew (according to the New International Version, 20, 34: 'Jesus ... touched their eyes. Immediately they received their sight and followed him.'). Perhaps it is not accidental that Cropper shows herself hesitating in view of the question of whether she should plead for the possibility that Poussin had read the Dioptrique or not: in the French text on the subject, published in 1995 (Cropper, 'Toucher le regard' [note II], p. 6I6), she still suggests such a possibility writing that Poussin had read 'également Matteo Zaccolino' (emphasis added), while she renounces such a reference in the American version (Cropper and Dempsey [note II], p. 212).

96 - According to Specht, Descartes (note 2), p. 71, this machine - the only one Descartes ever developed - did not meet with great success.

97 - See Elizabeth Cropper, 'Poussin and Leonardo: Evidence from the Zaccolini manuscripts', Art Bulletin, 1980, pp. 570-83. For the impact of Alhazen on the writings of Poussin see above, note 56 .

98 - For such a - rather superficial - interpretation see Blunt, Art and Architecture (note 15), p. 290 where he writes - for the time being - still rather cautiousy: 'It is by no means certain that Poussin actually read Descartes', continuing then: '.. but it is still true to say that his conception 
of space composition is based on the same mathematically rational principles which governed Descartes's view of the material world'. It is the merit of Carrier, Poussin's Paintings (note 23), p. 72 to have demonstrated how Blunt in a former version of this section (The Heroic and Ideal Landscape in the Work of Nicolas Poussin', Foumal of the Warburg and Courtauld Institute, 7 (I944), p. I64) boldly wrote: '... it is true to say that his [Poussin's] conception of spatial composition corresponds exactly to the ideas to be found in the philosopher'. Carrier, p. 72, rightly answers: 'There is really no exact parallel between Descartes's mind-body dualism and Poussin's composition.' In the text by Lee (note 52 ) the inverse process can be observed: before stating on p. 225 very cautiously that Poussin was a man 'who may never actually have read Descartes', he nevertheless emphasizes that 'something closely akin to the Cartesian rationalism was strong in Poussin himself. ..'.

99 - Jutta Held, 'Poussins Mythosrezeption — Zur Struktur seiner Ovidschen Motive', Niederdeutsche Beiträge zur Kun'stgeschichte, 35 (1996), pp. 69 -98, here p. 92, note 43: 'Poussin ist hier ohne Frage ein Anhänger des Descartesschen, humanistischen Menscheñbildes, welches das wesentliche Zentrum des Menschen in seinem Bewußtsein, seiner Vernunft sieht.' According to this interpretation the centralized composition of this painting would hence be an 'appeal to the consciousness' (p. 92: '... der Appell an das Bewußtsein. ..'). In spite of its title, the article does not exclusively take paintings with Ovidian motives into consideration, but - see 'The Death of Germanicus', 'The Massacre of the Innocents' or 'The Judgment of Solomon' - also pictures with other subjects. Finally, the basic supposition that Poussin could have chosen independently the subject of his paintings appears to be problematic.

IOo - Giovan Pietro Bellori, Le vite de' pittori, scultorie architetti moderni (Rome, I672), p. 412: '. . . e giovò molto a Francesco [Duquesnoy] nello incaminarsi alla bellezza e proporzione delle statue, misurandole insieme, come si vede quella d'Antinoo'. See there also the illustration to this report with the plates on the pages $45^{6}$ - 9. Already Félibien in his Entretiens IV (note 75), p. I2 explicitly corrected this narration: based on the testimony by Jean Dughet he states that Poussin's studied these proportions not with Duquesnoy but with Alessandro Algardi.
IOI - In his book, Carrier, Poussin's Paintings (note 23), p. 59s. condemns the connection Poussin/Descartes to be a simple 'cliché'; it is, however, interesting to see him reactivating this 'cliché' himself three years later: in his article 'Poussin's Cartesian meditations: self and other in the selfportraits of Poussin and Matisse', Source — Notes in the History of Art, xv/3 (1996), pp. 29-35, Carrier interprets Poussin's self-portrait in the Louvre as visual pendant to the Meditationes de prima philosophia, published by Descartes in $164 \mathrm{I}-42$ in Latin. Already this linguistic fact (rather than the 'strange un-Cartesian lack of lucidity', lamented by Carrier concerning the frames in the background of the painting) is pleading in disfavour of his hypothesis because Poussin — see Bardon (note 87) — had only a feeble knowledge of Latin. But as Carrier in the end only asserts that the painter would have created a visual counterpart to Descartes's famous 'Cogito, ergo sum', Poussin could have found these words also in the fourth part of the Discours. Supposing that Poussin had painted his self-portraits in front of a mirror, Carrier draws a parallel between Descartes's words and Poussin's painting: such that every reader of Descartes's text would have to repeat his words 'I think, therefore I am', so every spectator of the painting would see the same picture Poussin observed while executing his portrait. It is almost superfluous to put forward in evidence the fundamental error behind this concept, obviously inspired by Velasquez's 'Las Meninas' and its arthistorical readings: while the ego of words such as 'I think, therefore I am' can be neuter, open to the identification of the reader, a self-portrait is by its definition - a highly specified and first of all individualized representation which in a categorical way excludes identification with other persons. Thus, the textual pendant to Poussin's self-portrait would have been a sentence like 'I, René Descartes, sitting here at Amsterdam in I637 and writing these words, I think, therefore I am'.

102 - Descartes in a letter from 26 March I6r9 to Beeckman: '... une science toute nouvelle', quoted by Samuel S. de Sacy, Descartes (Paris, I996), p. 75 .

103 - Charles Perrault, Les Hommes illustres, II (Paris, I700), p. 90. However, according to Fontaine (note 80 ), p. 118 , behind these words a certain irony would be audible.

104 - Nicolas de Malebranche, De la recherche de la verité (Paris, I674), Lib. III, Part. I, Cap. Iv, § 5, p. 55 . 